Tjalling C. Koopmans Research Institute Tpllizh. Aoopmen

Discussion Paper Series nr: 10-15

\title{
The impact of scale, complexity, and service quality on the administrative costs of pension funds: A cross-country comparison
}

Jacob A. Bikker

Onno W. Steenbeek

Federico Torracchi 


\section{Tjalling C. Koopmans Research Institute \\ Utrecht School of Economics \\ Utrecht University}

Janskerkhof 12

3512 BL Utrecht

The Netherlands

telephone $\quad+31302539800$

fax +31302537373

website www.koopmansinstitute.uu.nl

The Tjalling C. Koopmans Institute is the research institute and research school of Utrecht School of Economics.

It was founded in 2003, and named after Professor Tjalling C. Koopmans, Dutch-born Nobel Prize laureate in economics of 1975.

In the discussion papers series the Koopmans Institute publishes results of ongoing research for early dissemination of research results, and to enhance discussion with colleagues.

Please send any comments and suggestions on the Koopmans institute, or this series to J.M.vanDort@uu.nl

ontwerp voorblad: WRIK Utrecht

\section{How to reach the authors}

Please direct all correspondence to the first author.

Jaap Bikker*\#

Onno W. Steenbeek ${ }^{\sim}$

Federico Torracchi \#

*Utrecht University

Utrecht School of Economics

Janskerkhof 12

3512 BL Utrecht

The Netherlands.

\#De Nederlandsche Bank,

Supervisory Policy Division,

Strategy Department,

P.O. Box 98

1000 AB Amsterdam, Netherlands,

E-mail: j.a.bikker@dnb.nl

$\sim$ Erasmus School of Economics $\sim$ All Pensions Group (APG)

P.O. Box 1738

3000 DR Rotterdam

The Netherlands 


\title{
The impact of scale, complexity, and service quality on the administrative costs of pension funds: A cross-country comparison
}

\author{
Jacob A. Bikkerab \\ Onno W. Steenbeek \\ Federico Torracchi ${ }^{b}$ \\ ${ }^{a}$ Utrecht School of Economics, \\ Utrecht University

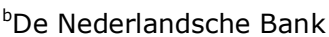 \\ the Netherlands \\ ${ }^{\mathrm{C}}$ Erasmus School of Economics, \\ Erasmus Universiteit \\ All Pensions Group (APG), ALM, \\ Risk Policy Department, Amsterdam
}

August 2010

\begin{abstract}
Administrative costs per participant appear to vary widely across pension funds in different countries. These costs are important because they reduce the rate of return on the investments of pension funds, and consequently raise the cost of retirement security. Using unique data on 90 pension funds over the period 2004-2008, this paper examines the impact of scale, the complexity of pension plans, and service quality on the administrative costs of pension funds, and compares those costs across Australia, Canada, the Netherlands, and the US. We find that, except for Canada, large unused economies of scale exist. Analyses on a disaggregated level confirm economies of scale for small and medium pension funds. Even though the pension funds in the sample are among the largest in the world, further cost savings appear to be possible. Higher service quality and more complex pension plans significantly raise costs, whereas offering only one pension plan reduces costs, as does a relatively large share of deferred (or sleeping) participants. Administrative costs vary significantly across pension fund types, with differences amounting to $100 \%$.
\end{abstract}

Keywords: Pension funds; Administrative costs; Scale economies; Service level; Complexity; Optimal scale.

JEL classification codes: G23. 


\section{Introduction}

Pension reforms, which have been at the center of the policy debates for many years, have gained even more urgency as a result of the credit crisis. Retirement savings are one of the most important assets for the majority of people in developed countries, and a well-functioning, low-cost system is therefore crucial. Although there is no consensus on what constitutes an optimal pension system, most policymakers acknowledge the importance of cost efficiency in pension provision. Even small differences in administrative costs can have a large impact on the net rate of return on pension contributions. Costs directly affect the extent to which the intended objective of providing adequate income for retirees can be attained. For example, an increase of one percentage point in annual charges on assets results in a reduction in future pension benefits of $27 \%$ after 40 years of contributions (Bateman and Mitchell, 2004). Although studies on investment costs as well as administrative costs incurred by pension funds are available, their number is limited in comparison to their topic's importance.

Administrative costs deserve greater research scrutiny, since they account for a very large portion of operational costs (Mitchell, 1998). However, difficulties in specifying the correct pension fund production function and the limited availability of data have hindered detailed empirical work on this topic. Moreover, so far empirical studies on economies of scale in pension fund administration have ignored service quality and the complexity of pension plans in the cost function. PricewaterhouseCoopers (PWC, 2007) argues that smaller funds offer a more expensive albeit more personalized service. Besides, customers benefit when they can choose among more flexible, customized, and varied services, even though these require a more sophisticated and costly administration. According to PWC (2007), differences in administrative costs are due not only to scale economies, but also to higher service quality and the more complex underlying business model of smaller funds. Where PWC had no data to support their view, our dataset enables us to test this hypothesis.

This study uses a unique and detailed dataset for pension funds from four countries, Australia, Canada, the Netherlands, and the US, covering the period 2004-2008, to shed light on a number of important questions related to administrative costs. First, we explore whether economies of scale in pension fund administration exist. If this is the case, pension fund participants can benefit from increasing the operational scale of pension funds, thereby lowering average administrative costs. A related question is whether the cost-size relation is concave, that is, whether an optimal scale exists with economies of scale for smaller pension funds and diseconomies of scale for larger ones. Second, we analyze the impact on administrative costs of service quality and the complexity of the pension plan. Third, we assess cost differences across pension fund types and pension plan types, pointing to possible systematic inefficiencies. Fourth, we explore cross-country differences and quantify the possible 
effects of institutional differences on costs, while controlling for a variety of factors. Finally, we focus on each of the specific disaggregated administrative operations and assess whether economies of scale are present, to establish where scale upgrading would realize the largest benefits.

The remainder of this paper is as follows. Section 2 reviews the existing literature on the administrative costs of pension funds, with particular emphasis on cross-country comparisons. Section 3 discusses and compares the main institutional features of the pension system in the four countries in our sample. Section 4 describes the dataset, reveals characteristics of pension funds, and explores the relations between administrative costs, pension plan complexity, and service quality on the one hand and size on the other. Section 5 presents the models used in the empirical analysis for two pension fund output measures, and discusses the empirical results. Finally, Section 6 recapitulates and draws policy recommendations.

\section{Review of the literature}

Administrative costs include all costs to operate the pension fund except investment costs, that is, personnel costs, costs charged by third parties, rent, depreciation, and so on. The administration of pension funds includes record keeping, communication with participants, policy development, and compliance with reporting and supervisory requirements (see also Table A.1 in the Appendix). Research on pension funds' administrative costs has focused on a few countries, in particular Australia (Bateman and Valdés-Prieto, 1999; Malhotra et al., 2001; Bateman and Mitchell, 2004; Sy, 2007), the US (Caswell, 1976; Mitchell and Andrews, 1981), Chile (James et al., 2001) and the Netherlands (Bikker and de Dreu, 2009). In all these countries, significant economies of scale were found for private pension funds with respect to both membership size and asset management. The main explanation is that overhead and other fixed costs (e.g., data management and compliance) can be spread over a larger pool of participants as membership size or financial wealth increases.

Ambachtsheer (2010) stresses the role of operational efficiency in optimal pension provision and indicates that more research is necessary on institutional implementation.

Few comparative studies have been done across different countries, and almost none have used a multivariate approach. Whitehouse (2002) compares defined contribution (DC) schemes in 13 countries. For Latin American countries and Great Britain, the author finds no systematic relation between pension fund size and charges levied (consisting of costs and profit margins), stating that evidence on economies of scale in pension fund administrative cost is inconclusive. In a more recent study, Hernandez and Stewart (2008) compare the charge ratios in 21 countries with private DC schemes. The authors note that charge ratios tend to be lower in countries with fewer providers, thereby concluding that there is some evidence of economies of scale. Tapia and Yermo (2008) 
conduct a similar analysis for countries in which the pension system is based on individual retirement accounts: Australia, Sweden, and countries in Latin American and Central and Eastern Europe. However, these studies do not distinguish between investment and administrative expenses, and use charge ratios or other measures of fees rather than economic costs. James et al. (2001) improve on this last issue by comparing fees and administrative expenses (including investment expenses) in six Latin American countries with pension systems based on individual retirement accounts. The fundamental problem with that body of research is the lack of appropriate data that would allow one to determine the relative contribution of each factor in a multivariate analysis. Instead, the authors use broad descriptive statistics on the domestic pension system to highlight bivariate relationships. Only Dobronogov and Murthi (2005) conduct a multivariate cross-country study, based on a limited number of observations, and find some evidence of economies of scale in pension funds in Croatia, Kazakhstan, and Poland.

In general, there are large differences in administrative costs among pension funds. Some of them reflect particular market conditions or institutional environments, while others are due to different degrees of efficiency. Nevertheless, Valdés-Prieto (1994) stresses that a comparison of economic efficiency both among pension funds and across countries is only meaningful if the quality of the services pension funds offer is accounted for. In his qualitative study of Chile, the US, Malaysia, and Zambia, Valdés-Prieto (1994) compares the quality of the national pension systems on broad quality dimensions. The author concludes that the variation in service quality across countries might be even higher than the variation in administrative costs. Mitchell (1998) indicates that an empirical estimation of the impact of service quality on the administrative costs of pension funds is very challenging, since it is difficult to measure service quality. This is an important problem, since Chlon (2000) suggests that customers value service quality and the provision of information more highly than the charges they have to pay. This view was confirmed by PWC (2007) based on a survey among participants.

There may be a difference between the costs that pension funds face and the fees they charge. Since pension funds typically do not seek profit, we would expect the two to coincide. However, privately run programs operating in imperfectly competitive markets (as, for instance, in the US) may enjoy some degree of market power and charge a price higher than production costs. Orszag and Stiglitz (2001) note that the distinction between costs and charges has been implicitly ignored by the academic literature or assumed to be of little relevance. The dataset in this study contains pure costs.

\section{Institutional setting of pension provision schemes across countries}

All countries' pension systems rely on a three-pillar structure, although this structure is much more institutionalized in Australia, Canada, and the Netherlands than in the US. In Australia, the first pillar 
is a publicly run system that aims at guaranteeing a minimum income for the elderly. Benefits depend on the level of income retirees receive from other sources and are financed from the general tax revenue. The second pillar is a compulsory, privately run pension program called the superannuation guarantee. This pension program was established in Australia in 1992, when it replaced a voluntary retirement system. Since 2002, employers have been required to save at least $9 \%$ of their employees' income, though low-earning workers are excluded from contributing. Workers can invest additional income in a voluntary third pillar comprising individual retirement accounts. Since the government allows employers great freedom to invest in the pension fund of their choice, pension funds differ substantially in terms of scale, plan type, form of management, and sponsor type. Plans can be acquired in the retail market or offered by the employer and are either single- or multi-employer plans, called, respectively, corporate and industry plans.

The pension system in Canada is very similar. The first pillar, created in 1952 through the Old Age Security Act, is financed through general taxation and offers a universal flat rate pension. The second pillar is a compulsory earnings-related social insurance program. Employees earning above a minimum level must contribute $4.95 \%$ of their earnings to a centrally administered plan that functions as a partially funded system. Employee contributions are $100 \%$ matched by the employer. Benefits depend on the contributor's history, and the program aims at a $25 \%$ replacement rate based on average lifetime salary. The Canadian third pillar comprises voluntary occupational and personal pension plans, known, respectively, as occupational registered pension plans and registered retirement savings plans. These registered pension plans can be operated under a trust agreement, under an insurance company contract, or under government-consolidated revenue funds for public employees. Most occupational plans are defined benefit (DB) plans, albeit DC plans are becoming more common in the private sector. In 2004, approximately half of the Canadian labor force saved through an occupational plan (Antolin, 2008).

In the Netherlands, the 1956 Pensions Act created a first-pillar pay-as-you-go system that entitles anyone above the age of 65 to a basic pension. The second pillar is a so-called quasi-mandatory system: The government itself does not mandate occupational schemes but, in practice, labor agreements ensure that $80 \%$ of all occupational plans are mandatory and that more than $90 \%$ of the employees are covered (Organisation for Economic Co-operation and Development, hereafter OECD, 2007). Both the employer and the employee contribute to funding. Generally, the employer provides around $70 \%$ of the pension contributions. A third pillar-encouraged through special tax rulesallows people to invest in individual pension plans.

The US pension system includes a public pension, Social Security, and a means-tested Supplemental Security Income for low-income retirees. Social Security is a pay-as-you-go system financed through 
a $12.4 \%$ payroll tax equally shared between employee and employer. The Supplemental Security Income is financed through the general government budget. Apart from mandatory payroll contributions to Social Security, there is no compulsory occupational or individual pension scheme. The government only mandates minimum standards for pension fund operations contained in the 1974 Employee Retirement Income Security Act and subsequent amendments. Employers or groups of employers are free to set up pension plans for their employees according to their own preferences. In the past, most plans were DB in nature, but today most of them are either DC or a hybrid. One popular plan is the 401(k) scheme, under which employees can retain part of their earnings in an account often partially matched by employers. Lastly, individual accounts known as Individual Retirement Accounts (IRAs) offer an additional vehicle to save for retirement. Voluntary plans are subject to contribution ceilings as well as special tax provisions that encourage savings. At the end of 2005, voluntary occupational pension schemes covered approximately 143 million participants, while individual plans covered 51 million participants (OECD, 2009b).

The institutional features of these four systems differ widely. First, while participation in an occupational scheme is mandatory in Australia and Canada, and, in practice, also in the Netherlands, it is not in the US. Second, average replacement rates are much higher in the Netherlands than in the other countries, although Canada has comparable rates for low-income retirees. Moreover, the replacement rate is flatter under the Dutch system than in the three other countries, where the rate declines faster for higher incomes. Antolin (2008) argues that the mandatory nature of a program and its generosity are important factors in determining participation in a voluntary pension plan. For instance, the enrollment rate in voluntary plans in the US is high, since the second pillar is not compulsory and public pensions are relatively meager. Furthermore, the combination of a quasimandatory second pillar and high targeted replacement rates makes the Netherlands one of the few countries - with Australia —in which the total assets of second pillar pension funds exceed $100 \%$ of the annual gross domestic product (hereafter GDP; see Table 1). Lastly, in terms of operating expenditure, there is variation among the four countries. As shown in Table 1, operating expenditures—which includes both administrative and investment costs—are smaller in Australia than in the other countries. However, these figures should be taken with caution, because costs are difficult to define uniquely across countries. Furthermore, for some countries, these figures fluctuate heavily over time.

All in all, we observe that the pension sector differs widely across countries, a finding that holds to a lesser degree also for the second pillar, where the pension funds operate. The US deviates from the other countries because they provide three different pension provision schemes in the first two pillars. Furthermore, the second pillar is mandatory in Australia, Canada, and the Netherlands, whereas in the US it is not. 
Table 1. Pension fund industry overview by country (OECD global pension statistics) ${ }^{\mathrm{a}}$

\begin{tabular}{|c|c|c|c|c|c|c|}
\hline Country & & 2004 & 2005 & 2006 & 2007 & 2008 \\
\hline \multirow[t]{4}{*}{ Assets to GDP (\%) } & Australia & 71 & 80 & 90 & 110 & 92 \\
\hline & Canada & 48 & 50 & 54 & 62 & 51 \\
\hline & Netherlands & 108 & 122 & 126 & 138 & 114 \\
\hline & US & 74 & 74 & 79 & 79 & 58 \\
\hline \multirow[t]{3}{*}{ Contributions to GDP $(\%)^{\mathrm{b}}$} & Australia & 7.23 & 7.81 & 8.80 & 15.98 & 9.74 \\
\hline & Canada & 2.30 & 2.24 & 2.57 & 2.56 & 2.15 \\
\hline & Netherlands & 4.64 & 4.97 & 4.44 & 4.26 & 4.02 \\
\hline \multirow{3}{*}{$\begin{array}{l}\text { Operating costs to assets } \\
(\%)^{\mathrm{b}, \mathrm{c}}\end{array}$} & Australia $^{\mathrm{d}, \mathrm{e}}$ & 0.31 & 0.30 & 0.28 & 0.27 & 0.30 \\
\hline & Canada & 0.85 & 0.64 & 0.72 & 0.28 & 1.38 \\
\hline & Netherlands & 0.77 & 0.79 & 0.61 & 0.55 & 0.51 \\
\hline \multirow{3}{*}{$\begin{array}{l}\text { Total number of pension } \\
\text { funds }{ }^{b}\end{array}$} & Australia $^{\mathrm{d}}$ & 1,785 & 1,323 & 872 & 575 & 505 \\
\hline & Canada & 3,816 & 3,816 & 5,036 & 5,036 & n.a. \\
\hline & Netherlands & 843 & 800 & 768 & 713 & n.a. \\
\hline
\end{tabular}

\section{Dataset}

Our dataset was provided by CEM Benchmarking (CEM) and contains 90 different second pillar pension funds from Australia, Canada, the Netherlands, and the US. ${ }^{4}$ This dataset is based on selfreported expenses rather than charges, and thereby circumvents some of the empirical problems mentioned in Section 2 on the literature review. The pension funds in our sample have an incentive to reveal accurate and truthful information to obtain targeted consulting and benchmarking. Our observations are from the period 2004-2008, resulting in an unbalanced panel with 254 observations. As shown in Table 2, the US accounts for 49 different pension funds and approximately two-thirds of the overall observations, including all first-year observations. For each pension fund, we have observations on the following: administrative costs, split into 24 cost categories (see the Appendix); the number of participants, split into three types, depending on their employment status; the number of pension plans; and information about service levels and complexity. The market value-that is, total assets - of the pension fund assets is missing for a number of pension funds, reducing the number of observations by one-quarter.

Our dataset is a non-random sample with respect to the overall population of pension funds, since CEM deals only with those pension funds that subscribe and pay for its benchmarking services. Our sample is small in terms of pension funds (compare Tables 1 and 2), but these pension funds are large in terms of participants, three (Australia) to 30 (Netherlands) times larger than the average pension

\footnotetext{
${ }^{4}$ CEM Benchmarking Inc. is a Toronto-based global pension benchmarking firm, focussing the objective measurement of the investment performance, service levels and costs of pension investments and administration.
} 
fund, covering 5\% (Australia) to $85 \%$ (the Netherlands) of all participants. ${ }^{5}$ Inferences about the overall pension fund industry would be inappropriate, and we instead assume that, at most, the sample is representative of the population of large pension funds in these four countries, restricting any conclusion to this particular set. Hence, one should recognize that the sample may suffer from selection bias.

Table 2. Sample observations of pension funds across countries and time

The column labeled All refers to the number of pension funds, while the Assets column refers to the number of pension funds that also provide their total assets.

\begin{tabular}{lccccccccccc}
\hline & \multicolumn{1}{c}{ Australia } & \multicolumn{3}{c}{ Canada } & \multicolumn{3}{c}{ Netherlands } & US & \multicolumn{2}{c}{ All countries } \\
\cline { 2 - 12 } & All & Assets & All & Assets & All & Assets & All & Assets & All & Assets \\
\hline 2004 & - & - & - & - & - & - & 31 & 12 & 31 & 12 \\
2005 & 9 & 0 & 8 & 4 & 9 & 5 & 28 & 15 & 54 & 24 \\
2006 & 5 & 0 & 11 & 7 & 12 & 11 & 34 & 31 & 62 & 49 \\
2007 & 10 & 9 & 12 & 10 & 12 & 12 & 41 & 41 & 75 & 72 \\
2008 & 3 & 3 & 3 & 3 & 0 & 0 & 26 & 26 & 32 & 32 \\
Total & 27 & 12 & 34 & 24 & 33 & 28 & 160 & 125 & 254 & 189 \\
$\begin{array}{l}\text { Proportion to } \\
\text { sample (\%) }\end{array}$ & 11 & 6 & 13 & 13 & 13 & 15 & 63 & 61 & - & - \\
$\begin{array}{l}\text { Number of } \\
\text { pension funds }\end{array}$ & 10 & 9 & 13 & 11 & 17 & 15 & 49 & 46 & 90 & 81 \\
\hline
\end{tabular}

Table 3 provides pension fund characteristics by country. Monetary variables-namely, administrative costs and total assets—-have been converted in euros at purchasing power parity (using OECD weights) to adjust for cross-country differences and changes in the relative value of a currency. Furthermore, they are expressed in 2005 prices to account for inflation. The average pension fund in the sample has approximately 400,000 members and holds 35 billion euros in assets, corresponding to over 90,000 euros per participant. Four pension funds hold assets in excess of 100 billion euros, that is, more than the annual GDP of most countries. Australian pension funds tend to be smaller in all dimensions, while the average Canadian pension fund has fewer members but more assets per member. The average Dutch pension fund is more than twice as large in terms of membership.

Pension funds in the Netherlands, as well as in the US, tend to be among the cheapest, with average yearly administrative fees of, respectively, 69 and 64 euros per participant. Canadian and Australian pension funds are, on average, the most expensive, with sample means of 87 and 97 euros per year, respectively. Administrative costs as a percentage of total assets in Canada and the US are low, whereas those in the Netherlands are higher. These figures are, incidentally, all considerably lower than those usually found in studies of pension funds (see Section 2). As indicated above, the sample is biased toward the larger pension funds in each country. Compared to other countries, Dutch pension funds have much more deferred or dormant participants who are no longer employed and not yet retired. This is probably due to the structure of mandatory pension schemes: Employees cannot

\footnotetext{
${ }^{5}$ The smallest pension fund of our sample counts 13.000 participants.
} 
choose, so changing jobs often implies changing pension funds. Nowadays, workers can transfer their pension rights to a different pension fund, but this has not always been the case in the past.

Table 3. Weighted averages of pension fund characteristics by country

Country averages are over observations. An alternative is to average first over observations by pension fund, obtaining pension funds characteristics, and second over pension funds. If the second step is replaced by taking weighted averages, with the number of observations as weights, we again obtain country averages over observations.

\begin{tabular}{|c|c|c|c|c|c|}
\hline & Australia & Canada & Netherlands & $\overline{\mathbf{U S}}$ & All \\
\hline Entire sample & $\mathrm{N}=27$ & $\mathrm{~N}=34$ & $\mathbf{N}=\mathbf{3 3}$ & $\mathrm{N}=160$ & $\mathrm{~N}=254$ \\
\hline Number of participants (1000s) & 128 & 242 & 818 & 393 & 400 \\
\hline Administrative costs per part. (euros) & 97 & 87 & 69 & 64 & 71 \\
\hline Share of active participants $(\%)$ & 54 & 60 & 37 & 55 & 53 \\
\hline Share of deferred participants (\%) & 24 & 7 & 45 & 18 & 21 \\
\hline Share of pensioners $(\%)$ & 23 & 33 & 18 & 27 & 26 \\
\hline CEM complexity score ${ }^{a}$ & 0.1 & -0.4 & -0.4 & 0.2 & 0 \\
\hline Arithmetic average complexity score ${ }^{a}$ & -0.5 & -0.2 & -0.7 & 0.3 & 0 \\
\hline Principal comp. complexity score ${ }^{a}$ & -0.4 & -0.7 & -0.8 & 0.4 & 0 \\
\hline Subsample I & $\mathbf{N}=\mathbf{2 3}$ & $\mathbf{N}=\mathbf{1 7}$ & $\mathbf{N}=\mathbf{3 3}$ & $\mathrm{N}=156$ & $\mathrm{~N}=\mathbf{2 2 9}$ \\
\hline CEM service score $^{\mathrm{a}}$ & -0.6 & -0.1 & 0.0 & 0.1 & 0 \\
\hline Arithmetic average service score ${ }^{a}$ & -0.4 & -0.7 & 0.1 & 0.2 & 0 \\
\hline Principal complex. service score ${ }^{a}$ & -0.1 & 0.3 & -0.2 & 0.0 & 0 \\
\hline Subsample II & $\mathrm{N}=12$ & $\mathrm{~N}=\mathbf{2 4}$ & $\mathrm{N}=\mathbf{2 8}$ & $\mathrm{N}=125$ & $N=189$ \\
\hline Total assets, on average (billion euros) & 5 & 32 & 41 & 36 & 35 \\
\hline Asset per participant (1000 euros) & 61 & 132 & 72 & 93 & 93 \\
\hline Administrative costs per asset $(\%)$ & 0.25 & 0.08 & 0.19 & 0.07 & 0.10 \\
\hline
\end{tabular}

${ }^{a}$ All service and complexity scores reported here are standardized to allow for comparisons across the three measures. Thus, the overall sample mean is zero by construction. Note that not all 12 service measures are available for all 254 observations. For some observations the service score is an average over fewer underlying components. For this reason, the service scores are based on that smaller number of observations (see subsample I).

For 75 pension funds, Graph 1 presents 2007 figures of administrative costs against size in numbers of participants, both expressed in logarithms. Cost per participant ranges from 19 to 415 euro per annum, while size varies from 13 thousand to 2.7 million participants. The graph suggests a negative relationship between average costs per participants and size. Pension funds from the Netherlands (indicated by $\mathrm{N}$ ) are among the largest ones, followed by those from the US (U), as observed also from Table 3. Furthermore, pension funds in these countries are among the most efficient ones. At the other end, we find Australian pension finds (A) typically to be smaller and with higher cost, while those from Canada (C) take an intermediate position. 
Graph 1. Administrative costs against size of 75 pension funds (in logarithms; 2007)

A, C, N and U refer to pension funds from, respectively, Australia, Canada, the Netherlands and the US.

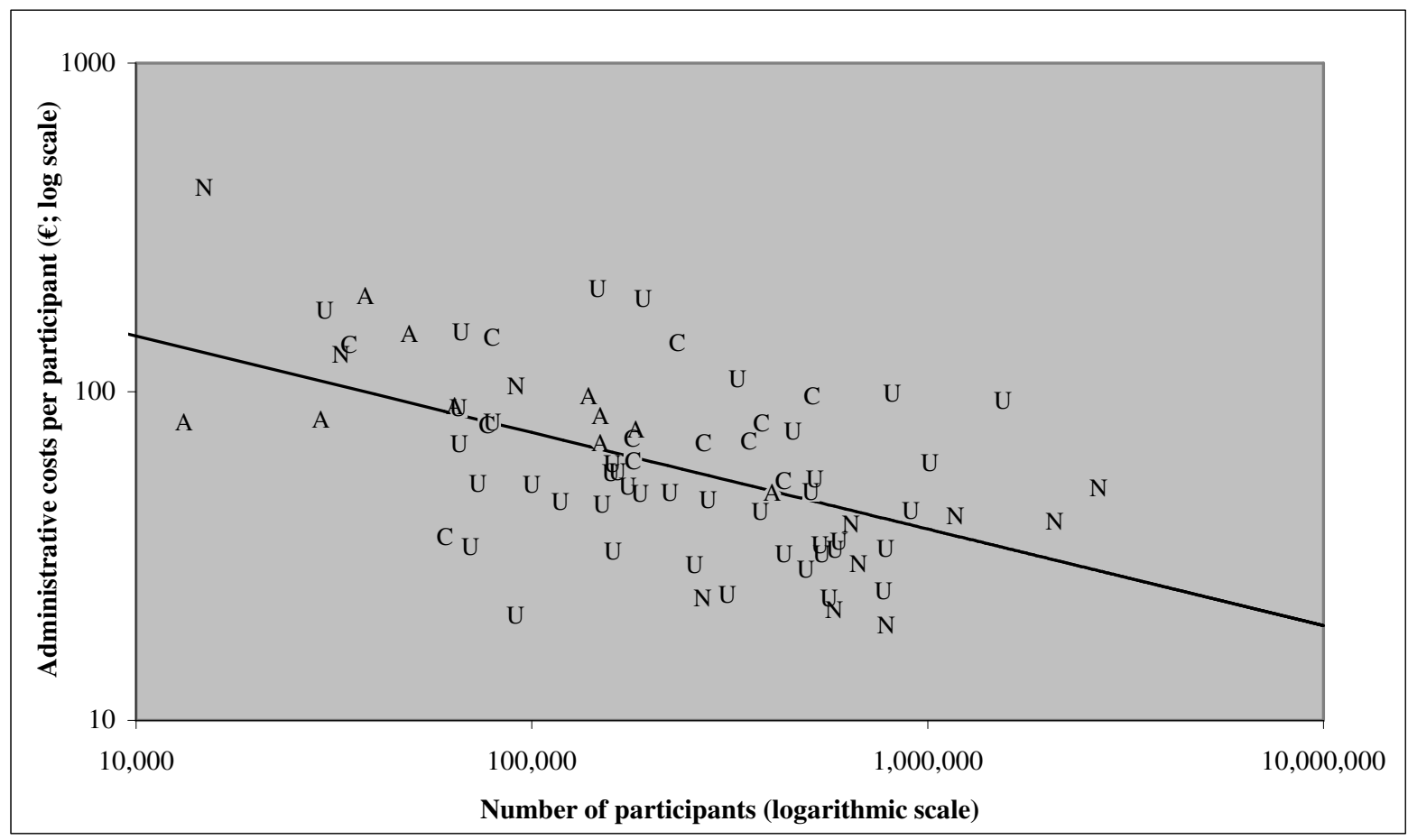

The dataset includes unique information on the service quality and the business model complexity of its pension funds. The benchmarking company defines service as "anything a member would like, before considering costs." Twelve variables capture several dimensions of the service quality of pension funds, such as timeliness in pension payments, amount and personalization of information, and services to employers of occupational funds. Each variable is the weighted average of finer and more precise measures (based on measures of activities of pension fund as well as satisfaction surveys among participants), and it is expressed on a 100-point scale. Table 4 provides an overview of the variables constituting the service quality score, as well as the weights used by the benchmarking company to construct an overall service score.

Similarly, 15 different variables describe the complexity of the pension fund's business model. Complexity refers to the intricacy of the rules governing pension payments, customized services, and contributions. ${ }^{6}$ Complexity variables are calculated as the weighted average of more specific measures of complexity, measured on a 100-point scale that increases with complexity. Table 5 shows the variables constituting the complexity score, as well as the weights used by the benchmarking company to construct an overall complexity score, which is the score used in our analysis.

\footnotetext{
${ }^{6}$ The 15 dimensions used to measure complexity are pension payment options, customization choices, multiple plan types and overlays, multiple benefit formula, external reciprocity, contractual cost-of-living-adjustment rules, contribution rates, variable compensation, service credit rules, divorce rules, purchase rules, refund rules, disability rules, translation, and defined contribution plan rules (see the Appendix).
} 
Table 4. The composite service score

\begin{tabular}{rlc}
\hline & Dimension & Weight (\%) \\
\hline 1 & Annuity pension payment & 18.9 \\
2 & Pension inceptions (excluding disability pension) & 7.9 \\
3 & Pension benefit estimates & 5.0 \\
4 & One-on-one member counseling & 7.9 \\
5 & Member presentations (group information sessions) & 6.7 \\
6 & Member contacts: calls, e-mails, letters & 21.5 \\
7 & Mass communication & 18.5 \\
8 & Service to employers & 4.0 \\
9 & Outgoing pension account transfers (refunds, transfers out, payment termination) & 0.3 \\
10 & Incoming pension account transfers & 3.3 \\
11 & Assessment of disability pensions & 5.1 \\
12 & Disaster recovery & 1.0 \\
\hline
\end{tabular}

The service and complexity variables are weighted averages, with the weights being determined by CEM analysts. To aggregate the 12 service variables into a single score, seven different criteria were employed: feedback from pension fund members (obtained at on-site meetings, symposiums, and peer conferences); the relative cost of each activity, ${ }^{7}$ the relative volume of each activity, the expectations of participants based on external experience, the extent of personalized human contact, the extent of participant resource involvement, and whether or not the dimension is related to the core business of the pension fund (i.e., generating and administering pension payments). These criteria do not translate directly into objective and indisputable weights, but are filtered through the professional judgment of several experts who eventually elaborate the weights to be used to summarize the information.

Although these values are updated every year to incorporate new feedback and past experience, some arbitrariness persists, potentially posing a threat to the validity of our analysis. We have no access to the original raw data used to compute the 12 dimensions of service quality or the 12 dimensions of complexity, but the dataset includes disaggregated data on these variables. To improve the robustness of the models, the composite score was calculated using two alternative operationalizations, namely, principal component analysis (PCA) and simple arithmetic averages. ${ }^{8}$ The latter solution is straightforward and results in a 100-point variable, while the former is discussed next in more detail.

The method of PCA involves taking an orthogonal linear transformation of a set of data to reduce a large dataset into a lesser number of factors, explaining as much variation in the original variables as possible. Because each factor retains the highest variance available, the inevitable loss of information in the data reduction procedures is minimized. In this instance, the generally low cross-correlations among the original dimensions imply a data structure that is not easy to interpret in terms of a few

\footnotetext{
${ }^{7}$ Later we introduce alternative weighting schemes (principal component analysis and equal weighted) that do not rely on costs.

${ }^{8}$ An alternative strategy would have employed each of the original 12 dimensions as explanatory variables in the final analysis, but the consequent reduction in the number of degrees of freedom available could have had severe implications, given the small sample at hand.
} 
Table 5. Weights used for the composite complexity score

\begin{tabular}{rlc}
\hline & Dimension & Weight $(\%)$ \\
\hline 1 & Pension payment options & 15.0 \\
2 & Customization choices & 20.0 \\
3 & Multiple plan types and overlays & 10.0 \\
4 & Multiple benefit formula & 16.0 \\
5 & External reciprocity & 3.0 \\
6 & Contractual cost-of-living-adjustment rules & 4.0 \\
7 & Contribution rates & 3.0 \\
8 & Variable compensation & 4.0 \\
9 & Service credit rules & 3.0 \\
10 & Divorce rules & 3.0 \\
11 & Purchase rules & 5.5 \\
12 & Refund rules & 4.0 \\
13 & Disability rules & 6.0 \\
14 & Translation & 0.5 \\
15 & DC plan rules & 3.0 \\
\hline
\end{tabular}

underlying variables, so that the criteria commonly employed to determine how many factors to retain do not lead to a clear solution. During an exploratory phase, the baseline model of administrative costs in Section 5 was estimated with several PCA specifications, differing only in the number of service and complexity factors retained. Since increasing the number of components did not substantially change the rest of the estimation, only the first component of each variable was maintained in the final analysis presented in this paper. ${ }^{9}$ The CEM and arithmetic average scores for services are higher for the US and the Netherlands, whereas the PCA score is higher for Canada. Complexity is, on average, higher in the US than in the other countries, but varying with the different measures (i.e., CEM, equalweighted, and PCA scores).

\subsection{Scale economies}

Table 6 presents average administrative costs for different-sized classes. The upper panel of Table 6 shows costs in relation to size classes based on the number of participants. The (weighted) average of administrative costs per participant falls steadily as the class size increases. The minimum value is 45 euros for pension funds having between half a million and a million members, reflecting unused economies of scale. For bigger funds, on average, the costs are higher. Apparently, scale economies exist even for the —on average - rather large funds in our sample. The average of administrative costs per total assets (weighted by the number of participants) does not indicate this U-shaped curve (although it would if medians were used). The data also present a clearly declining trend in individual financial wealth, since the value of individual assets in small pension funds is substantially higher than in larger ones. Lastly, it is worth noting that more expensive pension funds do not seem to deliver higher service quality. Although there is no clear relation and relatively little variation in service scores, the smallest pension funds offer the lowest service quality according to this measure, while the

\footnotetext{
${ }^{9}$ The first component of the PCA of the 12 service variables retains $26 \%$ of the original variance, while the first component of the PCA of the 15 complexity variables accounts for $21 \%$ of the original variance.
} 
largest pension funds provide the highest. Much stronger is the positive relation between pension fund size and the complexity score.

Table 6. Average annual administrative costs of pension funds by size classes

The upper panel of the table is weighted by the number of pension fund members, while the lower panel is weighted by the total value of pension fund assets.

\begin{tabular}{|c|c|c|c|c|c|c|c|c|}
\hline $\begin{array}{l}\text { Size classes } \\
\text { based on }\end{array}$ & $\begin{array}{c}\text { Number of } \\
\text { observations }\end{array}$ & $\begin{array}{l}\text { Administrat- } \\
\text { ive cost per } \\
\text { participant } \\
\text { (euros) }\end{array}$ & $\begin{array}{c}\text { Total } \\
\text { number of } \\
\text { participants } \\
\text { (millions) }\end{array}$ & $\begin{array}{c}\text { CEM } \\
\text { service } \\
\text { score } \\
(\mathbf{1 - 1 0 0 )} \\
\end{array}$ & $\begin{array}{c}\text { CEM } \\
\text { complex- } \\
\text { ity score } \\
(\mathbf{1 - 1 0 0 )}\end{array}$ & $\begin{array}{c}\text { Number } \\
\text { of obser- } \\
\text { vations }\end{array}$ & $\begin{array}{c}\text { Adminis- } \\
\text { trative cost } \\
\text { per asset } \\
(\%)\end{array}$ & $\begin{array}{c}\text { Assets per } \\
\text { participant } \\
(1000 s \\
\text { euros }) \\
\end{array}$ \\
\hline \multicolumn{9}{|c|}{ Number of participants $(\times 1000)$} \\
\hline$<50$ & 23 & 148.5 & 0.7 & 62.7 & 27.3 & 14 & 0.157 & 159.2 \\
\hline $50-100$ & 37 & 82.2 & 2.7 & 69.6 & 24.7 & 27 & 0.098 & 88.6 \\
\hline $100-500$ & 125 & 61.6 & 32.7 & 71.6 & 37.1 & 94 & 0.085 & 87.2 \\
\hline $500-1,000$ & 50 & 44.9 & 35.2 & 66.8 & 36.8 & 38 & 0.133 & 80.3 \\
\hline$>1,000$ & 19 & 55.1 & 30.3 & 73.9 & 40.1 & 16 & 0.085 & 74.1 \\
\hline \multicolumn{9}{|c|}{ Total assets (billion euros) } \\
\hline$<10$ & 64 & 81.4 & 8.9 & 71.5 & 27.7 & 64 & 0.115 & 91.6 \\
\hline $10-20$ & 41 & 52.0 & 10.6 & 71.8 & 34.4 & 41 & 0.085 & 68.5 \\
\hline $20-50$ & 44 & 74.8 & 19.3 & 70.6 & 36.6 & 44 & 0.077 & 106.4 \\
\hline $50-100$ & 27 & 51.3 & 21.8 & 73.0 & 38.2 & 27 & 0.052 & 110.1 \\
\hline$>100$ & 13 & 77.4 & 18.9 & 71.9 & 47.8 & 13 & 0.061 & 130.4 \\
\hline
\end{tabular}

The lower panel of Table 6 shows administrative costs in relation to size classes based on total assets.

The weighted average of the administrative cost per asset again reflects a U-shaped association: Costs decline very rapidly when the size class increases, reaching a minimum of $0.05 \%$ of total assets for pension funds with total assets between 10 billion euros and 100 billion euros (pointing to unused economies of scale) before slightly increasing again. The (weighted) average of administrative costs per participant, however, does not show a similar shape. These patterns are similar to those for all 700 Dutch pension funds (Bikker and de Dreu, 2009). Again, the quality of services seems to be approximately the same across asset classes, where complexity increases with size. The Appendix shows that economies of scale are also present on a disaggregated level, where the costs of most categories of administrative activities per participant decline with size. Section 5 uses a multivariate model of pension fund administrative costs to further investigate economies of scale.

\subsection{Additional number of pension plans and other services}

Table 7 compares the administrative costs for pension funds offering multiple products and services. The two upper rows of Table 7 contrast pension funds offering only one type of plan (which is mostly DB in the dataset) and those that allow clients to choose between two or three plans. The weighted average of administrative costs per participant is 57 euros in the first case and 55 euros in the second. On the other hand, costs are higher in the latter instance if expressed as a percentage of pension fund assets. Nonetheless, contrary to economic theory and observations elsewhere (Mitchell and Mulvey, 2004, p. 350), the data suggest that there is little substantial difference in administrative costs for pension funds offering more than one type of plan. The complexity score decreases when several plans 
are offered, probably indicating that DB plans are more complicated than DC schemes. Comparing pension funds that focus on their core business of providing pension plans versus those that provide additional services (such health cost administration, tax deferred savings plans, home mortgages, loans, and asset management), we find that the weighted average of the (normal) administrative cost per participant does not rise. This is in line with expectation as our 'normal' administrative cost does not cover cost of additional services. The complexity score increases with additional services, from 33 to 38 , while at the same time service quality also increases considerably, significant at the $1 \%$ level. Apparently, pension fund members appreciate the provision of supplementary services.

Table 7. Impact of additional number of pension plans and other services

Averages, weighted by the number of participants.

\begin{tabular}{llcccccc}
\hline & & $\begin{array}{c}\text { No. } \\
\text { of } \\
\text { obs. }\end{array}$ & $\begin{array}{c}\text { Administrat- } \\
\text { ive cost per } \\
\text { participant }(\mathbf{6})\end{array}$ & $\begin{array}{c}\text { Complexity } \\
\text { score CEM } \\
(\mathbf{1 - 1 0 0})\end{array}$ & $\begin{array}{c}\text { Service } \\
\text { score CEM } \\
(\mathbf{1 - 1 0 0})\end{array}$ & $\begin{array}{c}\text { No. } \\
\text { of } \\
\text { obs. }\end{array}$ & $\begin{array}{c}\text { Administrat- } \\
\text { ive costs per } \\
\text { asset }(\%)\end{array}$ \\
\hline Number of & One & 166 & 56.4 & 43.1 & 70.1 & 126 & 0.096 \\
plans offered & More than one & 88 & 54.2 & 34.3 & 70.7 & 63 & 0.104 \\
Additional & Zero & 48 & 55.7 & 32.8 & 65.1 & 29 & 0.095 \\
services & One or more & 206 & 54.9 & 38.2 & 71.3 & 160 & 0.102 \\
\hline
\end{tabular}

\section{Empirical analysis}

Section 4 describes bivariate relations between average administrative costs and pension fund size, country, service quality, pension scheme complexity, and other pension fund characteristics. This section examines the marginal contribution of each variable to total cost through a multivariate panel analysis. We use a traditional cost function to explain administrative costs, taking into account, among other variables, all the cost determinants considered above. In theoretical frameworks, such a cost function relates the total administrative cost of a pension fund to its output volume and input prices. Pension funds provide several services, but their key functions are "financing, recordkeeping, money management, and benefit payouts" (Mitchell, 1999, p. 3). Defining output is a well-known problem in the financial service industry. This paper uses both a narrow and a broad definition of output. The narrow measure of output, which will be central in our analysis, is the number of participants. This definition assumes that a pension fund's services are all related to the process of providing pension benefits to the fund's members, covering "financing, recordkeeping and benefit payouts." This output definition is closely linked to the pension fund activities behind our topic of investigations, that is, administrative costs. In reality, however, output is multidimensional. Therefore, we use as an alternative measure of output the log-linear combination of the number of participants and total assets, where the latter is a proxy of "money management" activities. Note that our investigations focus on administrative activities and do not regard the performance of investments as such. 
We start by estimating the impact of our narrow output measure membership size (Participants) on pension fund total administrative costs $(A C)$, while controlling for complexity and service quality scores and other determinants of administrative costs:

$\ln A C_{i j t}=\alpha+\beta \ln$ Participants $_{\mathrm{ijt}}+\gamma$ Service $_{i j t}+$ SComplexity $_{i j t}+\sum_{k} \zeta_{k}$ Control $_{i j t k}+\sum_{k=1}^{3} \eta_{k}$ Country $_{k}+\varepsilon_{i j t}(1)$

where $j$ refers to countries, $i$ to pension funds, and $t$ to time. We use logarithms to transform the administrative costs and number of participants to reduce the impact of heteroskedasticity, as well as enable the measurement of scale economies. The coefficient of the output variable, $\beta$, measures economies of scale $(\beta<1)$ or diseconomies of scale $(\beta>1)$ of the administrative activities of pension funds. Testing $\beta=1$ is equivalent to testing the null hypothesis that administrative costs rise (exactly) proportionally with the pension fund size, that is, that economies or diseconomies of scale do not exist. To investigate whether scale economies are constant across size classes or not, we also include, as a sensitivity test, a squared term of pension fund sizes (i.e., numbers of participants).

The service quality and complexity scores are important control variables, since they correct for additional costs due to extra services and tailor-made qualities. These variables are missing from all other existing pension fund costs studies. We apply either CEM scores, equal-weighted scores, or principal component scores, standardized to enable proper comparisons across the models. ${ }^{10} \mathrm{We}$ also control for the effects of pension fund types, actually their participants' occupations. Pension funds in the sample offer occupational plans for the public sector (national, local, or municipal governments), teachers, other school employees (custodians, administrative clerks, and other staff members), policemen, firemen, and other employees of public safety agencies, workers covered by a corporate or an industry-wide collective agreement, and workers in other occupational categories, such as judges. ${ }^{11}$ These categories are not mutually exclusive, because any pension fund can offer several occupational plans. A dummy variable for each type of occupation is included in the model to measure for each pension fund, whether or not it has participants working (or who have worked) in the respective type of occupation. Furthermore, the proportions of retired and deferred participants are included to take into account the impact of membership composition on the relative importance of the services performed. For instance, a pension fund with a high proportion of retirees should spend more, all else being equal, on annuity payment administration than one with a lower fraction of retirees, while sleepers are expected to be least costly, since many administrative activities have ended (e.g., incasso) or not yet started (payment of benefits). We also include the number of pension plans (one or more),

\footnotetext{
${ }^{10}$ The standardization is executed any time the sample size changes, so that in every subsample analyzed the mean equals zero and the standard deviation is one.

${ }^{11}$ Clearly, most of pension funds deal with public sector employees, but private sector employees are also present.
} 
where we expect a positive coefficient, since additional pension schemes complicate the pension fund bureaucracy and internal organization.

A country dummy is included to take care of fixed effects, such as labor market conditions and institutional structures, that are peculiar to each country. The US acts as the reference group. Finally, $\varepsilon_{i j t}$ is the idiosyncratic error term. Some of the theoretically relevant variables are not available for the individual pension funds, particularly input prices such as wages. For small countries such as the Netherlands, one might expect wages to be rather constant across the financial institutions. This case is less likely for large countries, for example, the US. We have country-wide (real) wages for the financial sector at hand, which would take wage differences across countries into account, while ignoring domestic differences across pension funds. Inclusion of the national wage levels in the model, as proxy for the input price for labor, produces insignificant coefficients ${ }^{12} \mathrm{We}$ decided to not include these input price proxies in Equation (1) for two reasons: (i) our wage price proxy is poor, and (ii) our country dummies would anyway absorb the level of such national wage prices (though not their eventual changes over time).

All models in this paper are unbalanced panels with random effects specific to pension funds. It is common practice to test the validity of this assumption of random effect (versus fixed effects) through the Sargan-Hansen test for overidentifying conditions. However, we have a strong economic argument not to use the fixed effect model, since pension-fund-specific fixed effects would not so much eliminate the effect of disturbing omitted variables (as it should do) but rather wipe out the size of the pension fund, disturbing the estimation of economies of scale. ${ }^{13}$ This has been tested empirically: fixed effects cause a strong downward bias of the output coefficient, strongly overestimating scale economies. OLS estimates do not deviate significantly from the random effect estimates.

\subsection{Empirical results for the narrow definition of output}

Table 8 presents the estimation results for the multi-country and US subsamples, both based on Equation (1). In addition, the multi-country model is estimated with individual-country interaction effects with output to measure the national extent of economies of scale, using $\Sigma_{k} \beta_{k}$ (ln Participants $\times$ Country $_{i j t}$ ) instead of $\beta$ (In Participants). For the multi-country model, substantial unused economies of scale seem to exist (first column). The scale coefficient of the number of participants indicates that total administrative costs increase by only $76 \%$ when membership size doubles. These potential economies of scale of $24 \%$ are statistically significant at the $99 \%$ confidence level. Table 8 tests the

\footnotetext{
${ }^{12}$ This outcome occurs also when we would delete the country dummies. Inclusion of the wage levels do not affecting the other model parameters. Alternative estimation results are available on request.

${ }^{13}$ Note that we do include fixed effects for countries as well as, in a variant, for years.
} 
significance of all coefficients (say, $\beta$ ) against the null hypothesis $\beta=0$ and presents the results with asterisks (*). In addition, for the output coefficients, the more relevant tests against the null hypothesis $\beta=1$ - that is, constant returns to scale (no scale economies) — are performed, where degrees signs $\left({ }^{\circ}\right.$ ) indicate the significance of the deviation from $\beta=1$.

\section{Table 8. Administrative cost of pension funds explained by a narrow definition of the output measure}

The value terms administrative costs (the dependent variable) is converted into euros and expressed at the 2005 (euro) price level. The asterisks ***, **, and * denote, respectively, significance at the $99 \%, 95 \%$, and $90 \%$ confidence levels. For the scale variable number of participants, we denote values significantly different from one by degree signs $\left({ }^{\circ}\right)$ instead of asterisks, see the first rows. The Huber-White standard deviations correct for heteroskedasticity and are reported in parentheses.

\begin{tabular}{|c|c|c|c|}
\hline & \multicolumn{2}{|l|}{ Multi-country sample } & \multirow[t]{2}{*}{$\mathbf{U S}^{\mathbf{a}}$} \\
\hline & One scale parameter & $\begin{array}{l}\text { Country-specific } \\
\text { scale parameters }\end{array}$ & \\
\hline Number of participants (in logs), entire sample & $* * * /{ }^{\circ o \circ} 0.759(0.053)$ & & $* * * / \circ 0.809(0.089)$ \\
\hline Number of participants (in logs) in Australia & & $* * * /{ }^{\circ} 0.739(0.105)$ & \\
\hline Number of participants (in logs) in Canada & & $* * * 0.945(0.147)$ & \\
\hline Number of participants (in logs) in NL & & $* * * /{ }^{\circ o o} 0.691(0.069)$ & \\
\hline Number of participants (in logs) in US & & $* * * /{ }^{\circ o o} 0.788(0.089)$ & \\
\hline Standardized CEM service quality score & $* * * 0.064(0.018)$ & $* * * 0.063(0.018)$ & $* * * 0.063(0.018)$ \\
\hline Standardized CEM complexity score & $* * 0.044(0.018)$ & $* * 0.038(0.017)$ & $* * 0.056(0.023)$ \\
\hline Single pension plan offered & $-0.128(0.083)$ & $-0.129(0.084)$ & $-0.068(0.088)$ \\
\hline Share of retired participants $(\%)$ & $-0.002(0.005)$ & $-0.003(0.005)$ & $0.005(0.008)$ \\
\hline Share of deferred participants $(\%)$ & $* * *_{-} 0.014(0.003)$ & $* * *-0.014(0.003)$ & $* *_{-} 0.012(0.004)$ \\
\hline Public sector: national government & $-0.028(0.093)$ & $-0.006(0.096)$ & $0.043(0.175)$ \\
\hline Public sector: state or provincial government & $* * * 0.631(0.203)$ & $* * * 0.728(0.193)$ & $* * * 0.808(0.216)$ \\
\hline Public sector: municipality & $* * 0.106(0.047)$ & $* * 0.093(0.048)$ & $* * * 0.179(0.051)$ \\
\hline Collective agreement (CA): teacher & $*_{-} 0.126(0.072)$ & $-0.119(0.073)$ & $*_{-}-0.171(0.085)$ \\
\hline CA: other school employees & $0.033(0.048)$ & $0.026(0.049)$ & $0.010(0.050)$ \\
\hline CA: police and other public safety workers & $0.048(0.038)$ & $0.052(0.038)$ & $0.010(0.037)$ \\
\hline Collective agreement: other & $* * *_{-} 0.213(0.076)$ & $* * *_{-} 0.212(0.076)$ & $* * *_{-} 0.249(0.085)$ \\
\hline Corporate pension fund & $-0.071(0.064)$ & $-0.092(0.073)$ & \\
\hline Industry pension fund & $0.036(0.042)$ & $0.011(0.048)$ & \\
\hline Australian pension fund & $* * 0.349(0.166)$ & $0.933(1.559)$ & \\
\hline Canadian pension fund & $* 0.254(0.136)$ & $-1.599(1.966)$ & \\
\hline Dutch pension fund & $* * * 0.445(0.133)$ & $1.631(1.336)$ & \\
\hline Intercept & $* * * 7.383(0.668)$ & $* * * 7.035(1.073)$ & $* * * 6.540(1.042)$ \\
\hline Number of observations & 254 & 254 & 160 \\
\hline$\chi^{2}$ statistic $^{\mathrm{b}}$ & 345.2 & 354.4 & 151.6 \\
\hline $\mathrm{R}^{2}$, overall & 83.7 & 83.8 & 83.2 \\
\hline
\end{tabular}

${ }^{a}$ The US does not have pension funds in the corporate and industry pension fund categories, and these dummies variables have therefore been dropped.

${ }^{\mathrm{b}}$ Joint significance of coefficients.

This multi-country output coefficient may hide country-specific scale effects. Therefore, in the second column, we estimate a modified version of Equation (1), where the pension fund size in terms of number of participants interacts with a country dummy to allow for cross-country comparisons of scale efficiencies. This specification assumes that the impact of all variables, except for membership size, on administrative costs is the same, regardless of the country in which the pension fund operates. Although the validity of this assumption is debatable, the specification is an improvement from the 
baseline model that assumes all relations between the dependent and independent variables to be the same. Fully separated country-specific estimates would require fewer assumptions, but are less reliable due to the low number of observations for all separate countries but the US. For three countries we observe the existence of highly significant scale economies, while for Canada the output coefficient is not statistically different from one, indicating that pension funds in this country are already operating on an efficient scale. The Netherlands is the country in which potential economies of scale remain for the relatively largest part unexploited. The scale coefficient, significant different from one at the $99 \%$ confidence level, suggests that doubling the membership size would increase costs by only $69 \%$, equivalent to potential economies of scale of $31 \%$. This is in line with results found by Bikker and de Dreu (2009) for all Dutch pension funds. Similarly, increasing membership by $1 \%$ in Australia and the US corresponds to an increase in total costs of $0.74 \%$ and $0.79 \%$, both of which are also significantly different from one at the $99 \%$ level. Finally, the last column of Table 8 shows the result of analyzing the subsample of only US observations. This exercise confirms the existence of scale economies in the US at the 95\% level. All three models have also been estimated with an additional squared term of the output measure number of participants. ${ }^{14}$ All squared terms have a positive sign, which is coherent with the hypothesis of a standard convex cost function, but their coefficients are statistically significant at the $90 \%$ level of confidence only, not at the $95 \%$ level, and, therefore, have been deleted in all presented model specifications. Bikker and de Dreu (2009) did observe significant squared terms using a large sample of the entire Dutch pension sector.

With respect to the control variable, we find, as expected, that both higher complexity and service quality increase total administrative costs, all else being equal. In all three specifications, they have significant and positive effects, respectively, at the 1\% significance level (service) and the 5\% significance level (complexity). This finding supports the obvious view that pension funds delivering service of a higher quality are, other things being equal, more expensive. Similarly, pension funds with a more complex business model are also more costly. The impact of service quality on administrative costs is similar across the various models in Table 8, but the impact of complexity on costs is somewhat higher in the US subsample. Offering only one policy plan decreases administrative costs by almost $13 \%$ in the multi-country model, and by $7 \%$ in the US sample, in line with expectations, but these effects are not statistically significant. While the percentage of retirees does not significantly reduce administrative costs, we observe a significant negative impact of the proportion of deferred participants, both multi-country and in the US, in line with expectations. This has also been found by Bikker and de Dreu (2009) for the entire Dutch pension sector.

\footnotetext{
${ }^{14}$ The results of the alternative estimations, here and elsewhere in this paper, are available on request from the authors.
} 
The nature of a pension fund's occupational plans is also an important factor in determining its administrative costs. Occupational plans covering employees of a state or provincial government or of a municipality have additional administrative costs of no less than $60 \%$ to $80 \%$ and $10 \%$ to $20 \%$, respectively. On the other hand, collective agreements covering teachers and workers in the "other" category decrease administrative costs, on average, by roughly $20 \%$. These relations are strongly significantly different from zero in all specifications. Hence, differences in administrative costs across pension fund types amount to around $100 \%$. Remarkably, these coefficients in the total sample and the US subsample are similar is sign and magnitude, be it that both positive and negative effects are more pronounced for the US in all four pension fund types mentioned. Relative (in)efficiency is an obvious explanation, but complexity and service quality may also play a role, as far as they have not been picked up by the two respective indexes, which, of course, are only general approximations.

Finally, there are also significant country-specific effects on administrative costs. Pension funds in Australia, Canadian, and the Netherlands are more costly than those in the US, all other determinants taken into account. These country dummies capture a large variety of effects, reflecting both the economic and institutional characteristics of the domestic pension fund markets, including (now the input prices are not incorporated in the regression) the national wage level (and other input prices at the country level), but not their eventual changes over time. However, when we include individual country interaction effects with the output measure number of participants, we no longer observe statistically significant country effects. Apparently, the dummies do pick up country-specific output measurement errors in the constrained model with one multi-country scale effect. The models explain no less than around $83 \%$ of the variation in the entire sample, as well as in the US sample.

If we replace the CEM scores for complexity and service quality by equally weighted or PCA scores, all the results are rather similar in coefficient sign, size, and significance. In fact, the three score measures are all mutually highly correlated, ${ }^{15}$ implying that they can be employed as substitutes without any major change in the model estimation. Using the first component derived from PCA is the optimal choice from a statistical point of view, because it can account for most of the variance in the original set of variables. On the other hand, using the CEM composite service and complexity scores is probably a better choice, since weights are assigned on the basis of professional judgment and experience. These alternative estimates suggest that different weights for the service and complexity dimensions have a limited impact on the estimation results. Thus, we retain here and later the original CEM scores as the variables measuring service quality and business model complexity, having

\footnotetext{
${ }^{15}$ If all observations are pooled, the coefficient of correlation between the original composite service score and the weighted average is 0.888 , that between the original service score and the first component is 0.966 , and that between the weighted average and the first component is 0.930 . If these coefficients are calculated for countryspecific subsamples, their values remain very high and in most cases exceed 0.900 ; only three out of 12 coefficients are below 0.900 , and none are below 0.850 .
} 
confidence in the judgment of experts who consider several criteria and place emphasis on the relative importance of each dimension.

\subsection{Empirical results for the broad definition of output}

Section 5.1 assumes that a pension fund's services are all related to the process of providing pension benefits to its members, where we call the number of participants the narrow measure of output. The last column in the upper panel of Table 6 indicates that assets per participant decline systematically with pension fund size, when expressed as the number of participants. Apparently, participants and total assets are related. More directly, part of the administrative activities may be related to the asset portfolio. Therefore, in this subsection we use as an alternative measure the combination of the number of participants and total assets (both in logarithms), where the latter is assumed to cover administrative costs related to investment management activities:

$\ln A C_{i j t}=\alpha+\beta_{1} \ln _{\text {Participants }_{\mathrm{ijt}}}+\beta_{2} \ln$ Totalassets $_{i j t}+\gamma$ Service $_{i j t}+\delta$ Complexity $_{i j t}+\sum_{k} \zeta_{k}$ Control $_{i j t k}$

$+\sum_{k=1}^{3} \eta_{k}$ Country $_{k}+\varepsilon_{i j t}$

Assuming a multiplicative output model, $\beta_{1}+\beta_{2}<1$ reflects economies of scale, $\beta_{1}+\beta_{2}>1$ diseconomies of scale, and $\beta_{1}+\beta_{2}=1$ constant returns to scale. To complement the analysis, we also apply country-specific interaction terms with, first, the number of participants and, second, total assets. Table 9 provides the estimation results of these broad definition specifications. The inclusion of total assets may enrich our model, but it reduces the number of available observations by one-quarter. For this reason we cannot just compare these outcomes with those in Section 5.1. The variable total assets appears to be a significant determinant of administrative costs in the multi-country sample (column 1 of Table 9). Apparently, administrative activities and their costs increase somewhat with the size of the investment portfolio. The inclusion of total assets reduces the size effect of the number of participants with 0.09 , so that the sum of these broad definition output coefficients $\left(\beta_{1}+\beta_{2}\right)$ is at $86 \%$ somewhat higher than the narrow definition output coefficient (76\%). However, this sum is also significantly lower than 1 (at the $99 \%$ level of confidence), confirming the existence of economies of scale. We draw a similar conclusion for the US, be it at the $95 \%$ level of confidence (column 3 of Table 9).

The inclusion of total assets also affects the coefficients of the other control variables. The service quality score is significant, as before, with similar coefficients. The variable single pension plan offered, however, is now significant, while the complexity score has lost its significance. Offering of a single plan, complexity, and total assets are interrelated, as also appears from their mutual correlation coefficients. A single plan is less complex, whereas complexity tends to increase with the financial 
size of the pension fund, as measured by its investment portfolio. ${ }^{16}$ The coefficients of the variables describing the degree of retirement and inactivity of participants do not differ essentially from those in the narrow output definition model.

\section{Table 9. Administrative costs of pension funds explained by a broad definition of the output measure}

Value terms (dependent variable administrative costs and explanatory variable total assets) are converted into euros and expressed at the 2005 (euro) price level. Asterisks ***,**, and * denote significance from zero at the $99 \%, 95 \%$, and $90 \%$ confidence levels, respectively. For the sum of the two scale variables total assets and number of participants, we denote "significantly different from one" by degree symbols $\left({ }^{\circ}\right)$ instead of asterisks (see the first row). The Huber-White standard deviations correct for heteroskedasticity and are reported in parentheses.

\begin{tabular}{|c|c|c|}
\hline & Multi-country sample & $\mathbf{U S}^{\mathbf{a}}$ \\
\hline Number of participants (in logs) & $* * * /{ }^{\circ o o} 0.671(0.072)$ & $* * * /{ }^{\circ o o} 0.631(0.090)$ \\
\hline Total assets (in logs) & $* * * 0.188(0.054)$ & $* * * 0.231(0.062)$ \\
\hline Standardized CEM service quality score & $* * 0.064(0.030)$ & $* * 0.060(0.024)$ \\
\hline Standardized CEM complexity score & $0.030(0.031)$ & $0.052(0.037)$ \\
\hline Single pension plan offered & $* * *-0.231(0.084)$ & $* *-0.198(0.094)$ \\
\hline Share of retired participants $(\%)$ & $-0.000(0.006)$ & $0.003(0.009)$ \\
\hline Share of deferred participants $(\%)$ & $* * *-0.013(0.004)$ & $* * *-0.014(0.005)$ \\
\hline Public sector: national government & $-0.030(0.079)$ & $0.041(0.157)$ \\
\hline Public sector: state or provincial government & $* * 0.523(0.229)$ & $* * * 0.673(0.236)$ \\
\hline Public sector: municipality & $* * 0.201(0.084)$ & $* * * 0.286(0.083)$ \\
\hline Collective agreement (CA): teacher & $* * *-0.260(0.089)$ & $* * *_{-} 0.287(0.091)$ \\
\hline CA: other school employees & $-0.081(0.062)$ & $-0.077(0.056)$ \\
\hline CA: police and other public safety workers & $0.008(0.039)$ & $0.001(0.038)$ \\
\hline Collective agreement: other & $* *-0.198(0.777)$ & $* * *-0.255(0.806)$ \\
\hline Corporate pension fund & $-0.093(0.111)$ & \\
\hline Industry pension fund & $*_{-0.196}(0.103)$ & \\
\hline Australian pension fund & $* * * 0.696(0.188)$ & \\
\hline Canadian pension fund & $* * 0.269(0.132)$ & \\
\hline Dutch pension fund & $* * * 0.629(0.138)$ & \\
\hline Intercept & $* * * 4.112(0.961)$ & $* * * 3.474 *(1.084)$ \\
\hline Number of observations & 189 & 125 \\
\hline$\chi^{2}$ statistic $^{\mathrm{b}}$ & 531.5 & 292.8 \\
\hline$\tilde{R}^{2}$, overall & 88.8 & 88.6 \\
\hline
\end{tabular}

a The US does not have pension funds in the corporate and industry pension fund categories, so these dummies variables have been dropped.

${ }^{\mathrm{b}}$ Joint significance of coefficients.

The pension fund type dummy coefficients hardly change: Only the significance level of the teacher pension fund category is now higher, the reason being that it has, on average, a larger investment portfolio, which is now incorporated in the model by the variable total assets itself. The country dummy coefficients have values similar to the ones cited before, but they depend strongly on the assumed multi-country scale effect: They become insignificant when the two scale parameters are country specific. ${ }^{17}$ The results for the US are similar to the multi-country outcomes. The goodness of

\footnotetext{
${ }^{16}$ Note that complexity and the number of participants are also strongly correlated at 0.4 , but this is less than the complexity and total assets correlation of 0.6 .

${ }^{17}$ In that case, the country-specific effects of total assets would be insignificant, apart for the US.
} 
fit is high, at more than $88 \%$. The additional explanatory variable total assets increases this measure by roughly $5 \%$.

\subsection{A disaggregated cost model}

As mentioned, so far the models investigate total administrative costs. A similar analysis is carried out at the micro level of cost components to analyze more in detail for which cost types we observe economies of scale. The disaggregated analysis includes all 24 cost types described in the Appendix, except those related to (1) disabled and other premium exceptions and (2) compliance with the Dutch pension fund supervisor's regulations, because only the 33 Dutch observations face these costs. ${ }^{18}$ The model being estimated is equivalent to that of Equation (1), but now each cost type is analyzed separately. ${ }^{19}$ In addition, for 12 of the remaining 22 administrative activities, we possess information on the service quality of that specific activity.

The idiosyncratic errors of Equation (1) applied to disaggregated activity $p, \varepsilon_{i j t p}$, are likely to be correlated with those of the other activities: If a shock hits one activity, other activities are likely affected too. This suggests that a seemingly unrelated regression (SUR) would increase the efficiency of the estimation. However, we instead run 22 separate regressions for two reasons: First, the SUR unbalanced panel estimator developed by Biørn (2004) uses a stepwise maximum likelihood procedure that does not converge in our estimation. Second, the number of observations across types of administrative costs is not the same; thus, the sample size would be sensibly reduced if all regressions were to be estimated through SUR. In short, the separate models produce unbiased and consistent results that might, however, not be efficient.

Table 10 presents the results for the 22 disaggregated administrative cost components. Here we show only the country-specific output coefficient $\beta_{i}$ from Equation (1) and the test results of the null hypothesis that the coefficient of the interaction term between the pension fund size and the country dummy variable is different from one, using asterisks. For most activities, there is evidence of economies of scale in at least one country, although we observe considerable variations in size. Significant economies of scale are most frequent for administrative activities in the Netherlands and the US. In addition, the average values per country, shown in the last row, clearly show that economies of scale are largest in these two countries. This finding is in line with what our

\footnotetext{
${ }^{18}$ The 22 activity-specific costs, listed in Table 10 and indicated by activity type number $p$, are investigated, except for the two pure Dutch activities $(p=23$ and 24). Activity-specific weighted service scores are used as explanatory variables in the activity-specific costs models when available, which is the case for $p=8,9,10,16$, 17, 18, 19, 20, 21, and 22 (apart from 23 and 24), whereas aggregated averages are included otherwise.

${ }^{19}$ But with interaction terms between the pension fund's country and its size, assuming again that the impact of all other variables on administrative cost components is the same regardless of the country wherein the pension fund operates. The results for the more simple specification with a single output variable for all countries are essentially the same. White standard deviations are calculated to adjust for heteroskedasticity.
} 
observations above, but the limited occurrence of economies of scale on a disaggregated level for Australia is remarkable, since we do find significant scale economies on the aggregated level. Most economies of scale are found for marketing and public relations and financial control with significant effects in three countries and as well as in board consulting, rules interpretation, and designing new rules, with significant effects in two countries. For almost any given administrative activity, pension funds in some of the countries are already operating at their optimal size (or close to it), while in other countries they are operating inefficiently, either because they are too large or too small.

\section{Table 10. Economies of scale in the 22 activity-specific costs}

The significance of output coefficients different from one (not zero, as elsewhere) are indicated with $* * *, * *$, and $*$, denoting the $99 \%, 95 \%$, and $90 \%$ confidence levels, respectively.

\begin{tabular}{|c|c|c|c|c|}
\hline \multirow{2}{*}{ Administrative activities } & \multicolumn{4}{|c|}{ Coefficient $\beta$ (standard deviation) } \\
\hline & Australia & Canada & Netherlands & $U S$ \\
\hline 1. Annuity pension payment & $1.24 *(0.14)$ & $0.79(0.18)$ & $0.77 * *(0.11)$ & $0.88(0.11)$ \\
\hline 2. Pension inceptions & $0.97(0.19)$ & $0.92(0.21)$ & $1.19 *(0.10)$ & $0.81 * *(0.08)$ \\
\hline 3. Benefit estimates & $0.61(0.24)$ & $1.00(0.25)$ & $0.48 * *(0.21)$ & $0.78 *(0.13)$ \\
\hline 4. One-on-one counseling & $0.84(0.35)$ & $1.43(0.43)$ & $0.43 * * *(0.18)$ & $0.89(0.12)$ \\
\hline 5. Member presentations & $1.05(0.24)$ & $0.45(0.46)$ & $0.35 * * *(0.19)$ & $1.01(0.18)$ \\
\hline 6. Member contacts & $0.88(0.15)$ & $0.99(0.18)$ & $0.88(0.10)$ & $0.89(0.09)$ \\
\hline 7. Mass communication & $0.89(0.16)$ & $0.94(0.24)$ & $0.84(0.11)$ & $0.74 * *(0.10)$ \\
\hline 8. Data \& contributions from employers & $0.78(0.19)$ & $0.74(0.20)$ & $1.10(0.11)$ & $0.84(0.13)$ \\
\hline 9. Other data & $0.92(0.53)$ & $0.67(0.23)$ & $0.74 *(0.14)$ & $0.59 * * *(0.12)$ \\
\hline 10. Billing and inspections & $0.61(0.28)$ & $0.35(0.56)$ & $1.15(0.14)$ & $0.34 * * *(0.24)$ \\
\hline 11. Service to employers & $1.17(0.37)$ & $1.47 *(0.26)$ & $1.11(0.14)$ & $0.91(0.11)$ \\
\hline 12. Refunds and transfers out & $1.08(0.25)$ & $0.81(0.17)$ & $0.80(0.13)$ & $0.71 * * *(0.11)$ \\
\hline 13. Purchases and transfers in & $2.50 *(0.81)$ & $1.14(0.27)$ & $0.95(0.17)$ & $1.11(0.18)$ \\
\hline 14. Assessment of disability pensions & $1.04(0.31)$ & $0.89(0.70)$ & $1.14(0.23)$ & $0.90(0.17)$ \\
\hline 15. Board of directors & $1.29(0.24)$ & $1.33(0.24)$ & $0.75(0.16)$ & $0.56 *(0.24)$ \\
\hline 16. Financial control & $0.95(0.19)$ & $0.61 * *(0.19)$ & $0.62 * * *(0.10)$ & $0.70 * *(0.14)$ \\
\hline 17. Board consulting & $1.19(0.34)$ & $0.79(0.42)$ & $0.14 * * *(0.26)$ & $0.28 * *(0.30)$ \\
\hline 18. Marketing and public relations & $0.04 * * *(0.34)$ & $1.51(0.58)$ & $0.46 * * *(0.18)$ & $0.49 * * *(0.19)$ \\
\hline 19. Rules interpretation & $0.91(0.24)$ & $0.67 *(0.19)$ & $0.49 * *(0.22)$ & $0.66^{* * *}(0.11)$ \\
\hline 20. Design new rules & $0.70(0.20)$ & $0.59 * *(0.20)$ & $0.58 * *(0.19)$ & $0.71 *(0.18)$ \\
\hline 21. Lobbying & $0.43(0.46)$ & $0.93(0.46)$ & $0.52 *(0.25)$ & $0.56 *(0.23)$ \\
\hline 22. Major projects & $0.73(0.31)$ & $0.36(0.98)$ & $0.85(0.18)$ & $1.09(0.22)$ \\
\hline Average values & $0.95(0.30)$ & $0.88(0.35)$ & $0.74(0.16)$ & $0.75(0.16)$ \\
\hline
\end{tabular}

On the country level, the Netherlands and the US show the greatest extent of scale economies, while (with smaller standard deviations) Australia and Canada shows less room to reduce total costs through scale effects. This finding is in line with what our findings for the economies of scale of aggregated administrative costs (see column 2 of Table 8). Interestingly, pension funds in the US and the Netherlands already tend to be among the cheapest and largest in the sample (see Table 3), yet most economies of scale can be found in these countries.

Analyzing the 22 models for the other coefficients, we find few consistent results across cost components. Service quality and business model complexity show fewer significant relations, but all those that are significant have a positive coefficient, in line with expectations. On the other hand, there 
is greater heterogeneity when considering the impact of different kinds of occupational activities, membership composition, and country-specific factors on administrative costs.

\section{Conclusions}

The administrative costs of pension funds are very important, for both sponsors and employees, since they may erode the wealth accrued for retirement. This study aims to shed light on a number of important questions related to the administrative costs of pension funds in four countries with welldeveloped pension systems. It explores whether economies of scale in pension fund administration exist, measures the impact on administrative costs of service quality and the complexity of the pension plan, and analyzes the impact of other cost determinants.

As expected, we find strong evidence of economies of scale, similar to those found in earlier studies, such as James et al. (2001), Tapia and Yermo (2008), and Bikker and de Dreu (2009). Overall, a 1\% increase in the number of participants would increase costs by $0.76 \%$. In the case where total assets are included in the model as a second output measure, costs would rise by $0.86 \%$ for a size increase of $1 \%$ for both the number of participants and the amount of total assets. When we allow for countryspecific scale effects, that is: different production processes across countries, we observe strong evidence of economies of scale for three out of four countries-Australia, the Netherlands, and the US-while constant returns to scale cannot be rejected for Canada. The scope for exploiting economies of scale is greatest for pension funds in the Netherlands and the US, even though these countries' pension funds already tend to be the largest and cheapest in the sample and their average administration costs are small relative to country-wide numbers (see, e.g., OECD, 2009a). Particularly for the Netherlands and the US, this outcome is confirmed when our model is applied on disaggregated administrative activities. Average costs per participants, both for our aggregated and disaggregated administrative activities, indicate a U-shape pattern, suggesting the existence of an optimal scale. However, when our model is based on the aggregated data, we do not find a statistically significant nonlinear effect. The results of this study support actions aimed at improving the efficiency of pension funds by consolidation, but not necessarily for very large pension funds. Note that all conclusions in this paper are under the reservation that our sample may not be fully representative of the countries' entire pension sectors.

Scale economy estimates could be biased when smaller pension funds systematically offer a more personalized service. Our dataset allows us to test such a bias, since we have data on complexity and service quality. First, we observe that smaller funds do tend to provide fewer rather than more services, while their pension plans are also are less complex, which does not point to tailor-made pensions. Apparently, the cost inefficiencies of smaller funds are not explained by higher service 
quality or cut-to-size pensions. This conclusion regards our sample, which underrepresents the smallest pension funds. Second, we include complexity and service quality as control variables in our administrative costs model and find that both complexity and service quality significantly increase administrative costs, as expected. Furthermore, we find that offering only one policy plan substantially decreases administrative costs. Both complexity and service quality are associated with costs, but the question is what pension plan members would select if they have a choice between higher service quality and more tailor-made options on the one hand and lower costs on the other.

Administrative costs vary significantly across types of pension funds. Pension funds for, for example, employees of state or provincial governments have a remarkable $70 \%$ higher level of administrative costs, and those for municipalities $10 \%$, other things being equal, while the costs for teacher and other (mainly non-public sector) pension funds have costs that are around $20 \%$ lower, all percentages being statistically significant. This finding points to huge potentials for efficiency improvements, on top of those stemming from consolidation. Finally, if we take all considered cost determinants into account, including country-specific scale economies, we do not observe any remaining cost difference across the four countries investigated. Hence, where the Dutch pension funds in our sample have, on average, relatively low administration costs, these are attributable to their larger scale, larger share of less costly deferred participants, and lower frequency of complex pension plans.

\section{Acknowledgments}

The authors are grateful to CEM Benchmarking, Inc., for providing the data, Jack Bekooij for excellent research assistance, and participants of the research lunch seminars of De Nederlandsche Bank (6 May 2010) and the Annual Netspar Pension Workshop, Zurich (10-11 June 2010). The views expressed in this paper are personal and do not necessarily reflect those of De Nederlandsche Bank and All Pensions Group.

\section{References}

Ambachtsheer, K., 2010. Future directions in measuring the financial performance of pension funds: A roundtable discussion. In: R. Hinz, R. Heinz, P. Antolin, J. Yermo (Eds.), Evaluating the Financial Performance of Pension Funds. World Bank, Washington, DC.

Antolin, P., 2008. Coverage of funded pension plans. OECD Working Papers on Insurance and Private Pensions, No. 19. OECD, Paris.

APRA, 2008. Statistics Annual Superannuation Bulletin 2008. Revised 2009. Last accessed October 15, 2009, http://www.apra.gov.au.

Bateman, H., Mitchell, O.S., 2004. New evidence on pension plan design and administrative expenses: The Australian experience. Journal of Pension Economics and Finance 3, 63-76.

Bateman, H., Valdés-Prieto, S., 1999. The mandatory private old age income schemes of Australia and Chile: A comparison. Mimeograph, University of New South Wales.

Bikker, J.A., de Dreu, J., 2009. Operating costs of pension funds: The impact of scale, governance and plan design. Journal of Pension Economics and Finance 8, 63-89. 
Biørn, E., 2004. Regression systems for unbalanced panel data: A stepwise maximum likelihood procedure. Journal of Econometrics 122, 281-295.

Caswell, J.W., 1976. Economic efficiency in pension fund administration: A study of the construction industry. Journal of Risk and Insurance 4, 257-273.

Chlon, A., 2000. Pension reform and public information in Poland, Pension Reform Primer series, Social Protection Discussion Paper. World Bank, Washington, DC.

Dobronogov, A., Murthi, M., 2005. Administrative fees and costs of mandatory private pensions in transition economies. Journal of Pension Economics and Finance 4, 31-55.

Hernandez, D.G., Stewart, F., 2008. Comparison of costs + fees in countries with private defined contribution pension system. Working Paper No. 6, International Organization of Pension Supervisions. Retrieved on October 10, 2009, from http://www.iopsweb.org/dataoecd/6/60/41269747.pdf.

James, E., Smalhout, J., Vittas, D., 2001. Administrative costs and the organizations of individual account systems: A comparative perspective. In: R. Holzmann, J. Stiglitz (Eds.), New Ideas About Old Age Security. World Bank, Washington, DC.

Malhotra, D.K., Marisetty, V.B., Ariff, M., 2001. Economies of scale in retail superannuation funds in Australia. Working paper, Monash University.

Mitchell, O.S., 1998. Administrative costs in public and private retirement systems. In: Feldstein, M. (Ed.), Privatizing Social Security. University of Chicago Press, Chicago, 403 - 456.

Mitchell, O.S., 1999. Evaluating administrative costs in Mexico's AFORES pension system. Pension Research Council Working Papers No. 1. University of Pennsylvania, Philadelphia.

Mitchell, O.S, Andrews, E., 1981. Scale economies in private multi-employer pension systems. Industrial and Labor Relations Review 34, 522-530.

Mitchell, O.S., Mulvey, J., 2004. Potential implications of mandating choice in corporate defined benefit plans. Journal of Pension Economics and Finance 3, 339-354.

OECD, 2007. Pensions at a Glance. OECD, Paris.

OECD, 2009a. Global pension statistics. Last accessed October 20, 2009, from http://oecd.org/daf/pensions/gps.

OECD, 2009b. OECD Private Pensions Outlook 2008. OECD, Paris.

Orszag, P. R., Stiglitz, J.E., 2001. Re-thinking pension reform: Ten myths about social security systems. In: Holzmann, R., J. Stiglitz (Eds.), New Ideas About Old Age Security. World Bank, Washington, DC.

PricewaterhouseCoopers, 2007. Kosten en baten van ondernemingspensioenfondsen [trans: Cost and benefits of corporate pension funds], PricewaterhouseCoopers, Amsterdam, 8 November 2007, from http://www.pwc.com/nl_NL/nl/pensioenland/assets/documents/opf-rapport.pdf).

Sy, W., 2007. Cost, performance and portfolio composition of small APRA funds. Working paper, Australian Prudential Regulation Authority, Sydney.

Tapia, W., Yermo, J., 2008. Fees in individual account pension systems: A cross-country comparison. OECD Working Papers on Insurance and Private Pensions, No. 27. OECD, Paris.

Valdés-Prieto, S., 1994. Administrative charges in pensions in Chile, Malaysia, Zambia, and the United States. Policy Research Working Paper, No. 1372. World Bank, Washington, DC.

Whitehouse, E., 2002. Administrative charges for funded pensions: An international comparison and assessment. Social Protection Discussion Paper Series No. 16, World Bank, Washington, DC. 


\section{Appendix: Costs of specific administrative activities}

The dataset includes information on the costs of specific administrative activities. To investigate the relation between size, service quality, complexity, and administrative costs, the latter are disaggregated into 24 different subcategories of activities: 1) annuity pension payments, 2) pension inceptions, 3) benefit estimates, 4) one-on-one counseling, 5) group presentations to members, 6) member contacts through mail, phone, and e-mail, 7) mass communication, 8) collection of data about and contributions from members via employers, 9) collection of data not via employers, 10) billing and inspections, 11) services to employers, 12) refunds and transfers out of individual pension accounts, 13) purchases and transfers in of individual pension accounts, 14) assessment of disability pensions, 15) the board of directors, 16) financial control, 17) board consulting, 18) marketing and public relations, 19) rules interpretation, 20) the design of new rules, 21) lobbying, 22) major projects, and - only for the Netherlands-23) disabled and other premium exceptions and 24) compliance with the supervisory regulations, that is, the regulations of the Central Bank of the Netherlands (DNB). While the sum of these types of administrative costs should equal total costs, in practice there are small discrepancies due to the way in which the data are collected. Besides, some of the pension funds (or some countries) in the sample either do not report or do not face certain administrative costs.

Table A.1 shows the average administrative costs over observations for each activity type, as well as across size classes, based on the number of participants. ${ }^{20}$ Note that detailed data are not available for all 254 pension fund-year observations. For most categories, there is a clear U-shaped curve, with average costs first declining with size and then increasing again, pointing to, respectively, economies and diseconomies of scale. In most cases (54\%), the minimum efficient scale is in the class of pension funds having between 500,000 and 1,000,000 members (see bold numbers in Table A.1). This follows also from the total administrative costs, the totals shown in the last row. For three categories (13\%), lowest average costs are obtained for the smaller class of 100-500 thousand participants. In some instances (33\%), average costs seem to diminish continuously, since the class size increases without any subsequent rise. In addition, in a few categories there is less regular relation between average costs and class size. Lastly, Table A.1 shows the incidence of different types of costs on the total administrative cost. ${ }^{21}$ In this respect, we observe heterogeneity across categories. Costs related to core business activities (annuity pension payment, pension inceptions, and data and contribution collection), individual and mass communication with members, financial control, and major projects are the main expenditure categories. At the opposite end, group presentations to members, board

\footnotetext{
${ }^{20}$ The weighted average costs of administrative activities are defined as $\Sigma_{n} w_{n} C_{i n}$, with $C_{i n}$ the administrative costs of activity $i$ for pension fund $n$. The weight of pension fund $n, w_{n}$, is defined as $p_{n} / \Sigma_{n} p_{n}$, with $p_{n}$ the number of participants of pension fund $n$.

${ }^{21}$ Weighted average incidence of different activities on total administrative cost is defined as $\sum_{n} w_{n} C_{i n} / A C_{n}$, with $A C_{n}$ the total administrative cost of pension fund $n$.
} 
consulting, marketing and public relations, and rule interpretation and design have the lowest incidence. These figures are important because economies of scale, to have a substantial impact on total administrative costs, should exist in activities that have a relative high incidence on total costs.

Table A.1. Costs of $\mathbf{2 4}$ administrative activities by five pension fund size classes.

For each cost category, the lowest average costs number is printed in bold.

\begin{tabular}{|c|c|c|c|c|c|c|c|c|}
\hline \multirow[b]{2}{*}{ Administrative activities } & \multirow{2}{*}{$\begin{array}{l}\text { No. } \\
\text { of } \\
\text { obs. }^{\text {a }}\end{array}$} & \multicolumn{6}{|c|}{$\begin{array}{c}\text { Average administrative cost per participant (in euros) by } \\
\text { class size, based on the number of participants }\end{array}$} & \multirow{2}{*}{$\begin{array}{l}\text { Weighted average } \\
\text { incidence on total } \\
\text { administrative } \\
\operatorname{costs}^{\mathrm{b}}(\%)\end{array}$} \\
\hline & & $<\mathbf{5 0 , 0 0 0}$ & $\begin{array}{l}50,000- \\
100,000\end{array}$ & $\begin{array}{c}100,000- \\
500,000\end{array}$ & $\begin{array}{l}500,000- \\
1,000,000\end{array}$ & $1,000,000$ & Total & \\
\hline Annuity pension payment & 250 & 9.2 & 4.1 & 4.3 & 3.0 & 2.5 & 3.3 & 6.0 \\
\hline Pension inceptions & 250 & 10.6 & 6.6 & 5.0 & 5.0 & 5.1 & 5.1 & 9.6 \\
\hline Benefit estimates & 247 & 4.6 & 3.2 & 2.8 & 1.2 & 1.2 & 1.8 & 3.3 \\
\hline One-on-one counseling & 236 & 8.0 & 2.2 & 2.0 & 1.8 & 1.3 & 1.7 & 2.9 \\
\hline Member presentations & 135 & 3.0 & 0.4 & 1.1 & 0.6 & 0.6 & 0.8 & 0.6 \\
\hline Member contacts & 254 & 12.3 & 7.0 & 6.1 & 4.4 & 3.9 & 4.9 & 9.3 \\
\hline Mass communication & 254 & 13.0 & 5.9 & 4.6 & 2.2 & 3.3 & 3.5 & 6.4 \\
\hline $\begin{array}{l}\text { Data and contributions } \\
\text { from employers }\end{array}$ & 250 & 9.3 & 7.0 & 5.5 & 4.1 & 5.2 & 5.0 & 9.8 \\
\hline Data not from employers & 234 & 6.5 & 2.8 & 1.4 & 1.6 & 2.0 & 1.7 & 3.5 \\
\hline Billing and inspections & 211 & 1.3 & 1.4 & 0.5 & 0.9 & 1.4 & 1.0 & 2.0 \\
\hline Service to employers & 230 & 1.7 & 2.9 & 1.9 & 1.3 & 2.7 & 1.9 & 3.8 \\
\hline Refunds and transfers out & 254 & 10.7 & 4.0 & 3.2 & 1.3 & 1.8 & 2.2 & 3.9 \\
\hline Purchases \& transfers in & 241 & 5.7 & 5.1 & 3.2 & 2.4 & 2.9 & 2.9 & 4.8 \\
\hline $\begin{array}{l}\text { Assessment of disability } \\
\text { pensions }\end{array}$ & 225 & 8.0 & 2.7 & 3.5 & 2.4 & 4.1 & 3.3 & 5.0 \\
\hline Board of directors & 238 & 10.4 & 4.3 & 2.3 & 0.8 & 1.1 & 1.6 & 2.9 \\
\hline Financial control & 254 & 23.2 & 9.9 & 4.2 & 2.3 & 4.5 & 3.9 & 6.8 \\
\hline Board consulting & 216 & 6.7 & 1.5 & 1.3 & 1.3 & 0.3 & 1.0 & 1.5 \\
\hline Marketing \& public relat. & 158 & 2.4 & 1.4 & 0.5 & 0.5 & 0.4 & 0.5 & 0.6 \\
\hline Rule interpretation & 238 & 5.5 & 2.5 & 1.3 & 1.3 & 0.8 & 1.2 & 2.2 \\
\hline Design new rules & 218 & 3.7 & 1.4 & 1.0 & 0.8 & 1.0 & 1.0 & 1.4 \\
\hline Lobbying & 183 & 2.1 & 0.9 & 0.8 & 0.3 & 0.4 & 0.5 & 0.7 \\
\hline Major projects & 203 & 18.8 & 12.9 & 9.1 & 7.5 & 11.3 & 9.2 & 13.1 \\
\hline $\begin{array}{l}\text { Disability and other } \\
\text { premium exceptions }{ }^{\mathrm{c}}\end{array}$ & 33 & 1.4 & 1.2 & 0.7 & 0.4 & 0.6 & 0.6 & - \\
\hline Compliance to DNB reg. ${ }^{c}$ & 33 & 4.0 & 3.1 & 0.7 & 0.6 & 0.2 & 0.4 & - \\
\hline Total $^{d}$ & & 168 & 86 & 62 & 44 & 54 & 55 & 100.0 \\
\hline
\end{tabular}

${ }^{\text {a }}$ Excluding observations for which the cost is zero.

${ }^{\mathrm{b}}$ The weighted average incidence is calculated excluding the costs of disability and premium exceptions and that of compliance with DNB regulations, because only Dutch pension funds face these types of cost. The numbers, however, are essentially the same if two costs are included.

${ }^{c}$ Only for Dutch pension funds (excluded in the panel analysis).

${ }^{d}$ The size class totals result from weighting with the respective numbers of observations divided by 250 . They compare to the figures in the second column of the upper panel of Table 6, denoting the administrative cost per participant. 